\title{
NCR3 wt Allele
}

National Cancer Institute

\section{Source}

National Cancer Institute. NCR3 wt Allele. NCI Thesaurus. Code C104549.

Human NCR3 wild-type allele is located in the vicinity of $6 \mathrm{p} 21.3$ and is approximately $4 \mathrm{~kb}$ in length. This allele, which encodes natural cytotoxicity trigg ering receptor 3 protein, is involved in natural killer cell function. 